\title{
Pemphigus Antibody Interaction with Human Epidermal Cells in Culture
}

\author{
A PROPOSED MECHANISM FOR PEMPHIGUS ACANTHOLYSIS
}

\author{
John R. SCHILTZ, Beno Michel, and Robert PAPAy, University Hospitals of \\ Cleveland, Department of Medicine, Division of Dermatology, Case Western Reserve \\ University School of Medicine, Cleveland, Ohio 44106
}

A B S TRACT The mechanism of pemphigus acantholysis has been studied with an in vitro system. Freshly prepared human skin epidermal cells were incubated in F-10 medium which contained the immunoglobulin $G$ fraction from either pemphigus serum or normal human serum. During 18 -h incubation periods, the pemphigus antibody became bound to the surface of the epidermal cells, caused the destruction of $75 \%$ of the viable cells as compared to only $14 \%$ in the normal immunoglobulin $\mathrm{G}$ controls (trypan blue exclusion), prevented the accumulation of newly synthesized proteins by nearly $60 \%$ as determined by radioactive tracer studies, and caused a dramatic shift in distribution of the newly synthesized proteins from an insoluble cell-associated fraction to an extracellular soluble fraction. These effects on the accumulation and partitioning of newly synthesized proteins were antibody concentration-dependent. Kinetic studies showed that at a fixed pemphigus antibody concentration the inhibition of protein accumulation preceded solubilization by about $1 \mathrm{~h}$, at which time rapid solubilization of up to $70 \%$ of the insoluble cellular material occurred. Several lines of evidence suggested that this phenomenon was caused by enzymatic activity. Epidermal extracts solubilized a prepared substrate of radioactively labeled insoluble epidermal cell material. This activity was heat labile and $\mathrm{pH}$ dependent, with $\mathrm{pH}$ optima ranging from 4.5 to 6.5 . Enzymes with $\mathrm{pH}$ optima between 6 and 6.5 were recovered in the culture medium after a 2-day incubation of pure, intact epidermis with the pemphigus antibody.

We propose the following hypothesis to account for pemphigus acantholysis. The pemphigus antibody reacts with the epidermal cell surface and produces such a severe disturbance that the integrity of the cell

Received for publication 16 January 1978 and in revised form 30 May 1978. surface is lost. As a result of these primary perturbations, the cell is killed and, during the process, responds by release or activation of soluble hydrolytic enzymes. This autolytic process results in the characteristic acantholysis of pemphigus.

\section{INTRODUCTION}

Pemphigus is a human disease characterized clinically by flaccid blisters which arise in stratified squamous epithelia of the skin and mucous membranes. Histologically, the blisters occur within the epidermis and the lesions are characterized by the presence of distinctive acantholytic cells (1). It has been shown that immunoglobulin (Ig)G antibodies are bound to the suprabasilar epidermal cells of patients with pemphigus (2) and that circulating serum IgG antibodies directed toward the epidermal cells are also present (3).

Definitive evidence that serum from pemphigus patients can produce the characteristic histological lesion of pemphigus has been established in organ culture studies with human (4-8) or monkey (9) skin. The antibody binds to the epidermal cells before the onset of acantholysis. Schiltz and Michel $(6,7)$ demonstrated that $(a)$ the IgG fraction from the pemphigus serum was responsible for the tissue damage, $(b)$ acantholysis occurred without participation of complement, and $(c)$ the suprabasilar epidermal target cells responded to the antibody by a net reduction in the accumulation of newly synthesized RNA and protein. Barnett et al. (10) and $\mathrm{Hu}$ et al. (11) have verified that the ultrastructural events which occur in culture of monkey or human skin, respectively, are similar to those which occur in spontaneous pemphigus (12).

Even though much new information concerning pemphigus acantholysis has been gained with skin in organ culture, this system has limited potential for biochemical studies of the mechanism. Consequently, 
we have studied the effects of the pemphigus antibody on human epidermal cells cultured as single cells in suspension or as intact epidermis. Our results suggest that the binding of the antibody to the epidermal cell initiates a series of events which result in the release or activation of hydrolytic enzymes from the cell and subsequent autolysis and acantholysis.

\section{METHODS}

Preparation and labeling of epidermal cell suspensions. The suspensions were prepared by a two-step process. In the first step, human skin pieces $\left(1 \mathrm{~cm}^{2} \times 0.3-\mathrm{mm}\right.$ thick) were incubated $1-2 \mathrm{~h}$ at $4^{\circ} \mathrm{C}$ with $0.4 \%$ trypsin (13) in Simm's $\mathrm{Ca}^{++}$ $\mathrm{Mg}^{++}$-free medium, and the epidermis was then separated from the dermis with a dissection microscope. In the second step, the epidermis was placed in $0.25 \%$ trypsin in Simm's $\mathrm{Ca}^{++}-\mathrm{Mg}^{++}$-free medium at $37^{\circ} \mathrm{C}$ for $1 \mathrm{~h}$, and accompanied by frequent shaking. Single cells and small clumps which were liberated were separated from the larger clumps and stratum corneum by passing over two layers of sterile lens paper (Fisher Scientific Co., Pittsburgh, Pa.) in a Swinney filter apparatus and the suspension was washed three times in F-10 medium that contained $10 \%$ fetal calf serum. This procedure yields from 1 to $5 \times 10^{5}$ cells per $\mathrm{cm}^{2}$ of epidermis and the viability ranges from 80 to $90 \%$ (trypan blue exclusion).

In all the experiments to be described, the cells were incubated in F-10 medium (14) which contained 0.01 times the normal concentration of amino acids plus purified pemphigus IgG or control human IgG plus a labeled amino acid mixture (NET-250 New England Nuclear, Boston, Mass.). No additional proteins were added to the incubation medium. The IgG fractions from pooled normal or pemphigus sera were prepared by a multiple ethanol precipitation procedure (15), and the final IgG precipitates were dissolved in and dialyzed extensively against F-10 medium. We have previously shown by immunoelectrophoresis that these fractions consist almost entirely of $\operatorname{IgG}(7)$. Because it is known that antibloodgroup antibodies react to antigens in the epidermis (16), serum from normal individuals with blood type $A B$ was the source of the normal IgG. The titers of intercellular cement substance $(\mathrm{ICS})^{1}$ antibodies were determined in the reconstituted pemphigus IgG stock solutions, and the titers used for the experiments were calculated, based upon dilution of these more concentrated stocks. Titers were determined with monkey esophagus as substrate, according to Beutner et al. (17) The protein concentration of the normal IgG for a given experiment was adjusted to that of the pemphigus IgG $(20-40$ $\mathrm{mg} / \mathrm{ml}$ ). The incubations were at $37^{\circ} \mathrm{C}$ in a humid atmosphere of $5 \% \mathrm{CO}_{2}: 95 \%$ air.

Preparation of fractions $I, I I$, and III from epidermal cells. A simple cell-fractionation scheme was devised to study the radioactive proteins synthesized by epidermal cells in culture. This scheme allowed for quantitation of the total newly synthesized proteins as well as evaluation of the partitioning of these proteins into an extracellular, medium-soluble fraction (fraction I), an intracellular, water-soluble fraction (fraction II), and a water-insoluble fraction (fraction III). Fraction I represents soluble proteins released from the cells into the medium during incubation with the isotope. Fraction II defines those soluble components released from cells after disruption by freeze/thaw. This fraction contains the soluble proteins from within the cell, and those which were solubilized by the freeze/

${ }^{1}$ Abbreviation used in this paper: ICS, intercellular cement substance. thaw technique. Fraction III contains water-insoluble cellular components and probably represents the major structural components of the cell. The following procedure was used to prepare these fractions. Fraction I: At the end of the incubation period, 2-3 $\mathrm{ml}$ of phosphate-buffered saline ( $\mathrm{pH} 7.2$ ) was added to each culture tube. The tubes were centrifuged at $1,700 \mathrm{rpm}$ for $5 \mathrm{~min}$ in the clinical centrifuge, and the supernate was removed. Fraction II: The cell pellet was suspended in $3 \mathrm{ml}$ distilled water, and the cells were ruptured by three cycles of freeze/thaw (dry ice in acetone followed by $37^{\circ} \mathrm{C}$ water bath). The broken cell suspension was centrifuged at $2,500 \mathrm{rpm}$ for $10 \mathrm{~min}$ in the clinical centrifuge, and the supernate removed. Fraction III: This last water wash was repeated twice and the supernates pooled with Fraction II. The remaining pellet was suspended in $3 \mathrm{ml}$ distilled water. All three fractions were then dialyzed $24 \mathrm{~h}$ against running tap water followed by $24 \mathrm{~h}$ dialysis against distilled water. All dialysis was at $4^{\circ} \mathrm{C}$. Partitioning was determined by measuring the radioactivity of aliquots in a Beckman LS 230 liquid scintillation counter (Beckman Instruments, Inc., Fullerton, Calif.) with a Triton X-100-based aqueous scintillation fluid (Rohm and Haas Co., Philadelphia, Pa.) (18). All counts per minute were corrected to disintegrations per minute with the use of the external standard on the scintillation counter.

Immunofluorescence. Immunofluorescence was used to demonstrate pemphigus IgG binding to epidermal cells. An epidermal cell suspension was incubated $1 \mathrm{~h}$ at $37^{\circ} \mathrm{C}$ in $0.5 \mathrm{ml}$ of F-10 medium which contained pemphigus IgG $(25 \mathrm{mg} / \mathrm{ml}$ antibody protein, anti-ICS titer $=160$ on monkey esophagus substrate). The cells were then centrifuged $(1,700 \mathrm{rpm}$ for 5 min in the clinical centrifuge), resuspended in $5 \mathrm{ml}$ phosphatebuffered saline plus $1 \%$ bovine serum albumin, and again centrifuged. This washing was repeated twice, and the pellet was suspended in a small volume of phosphatebuffered saline plus bovine serum albumin, spread on a glass slide, and air dried. The cells were then stained with fluoresceinconjugated, goat anti-human IgG (Hyland Laboratories, Inc., Costa Mesa, Calif.) for $30 \mathrm{~min}$. The conjugate was used at a dilution of 1:8 (fluorescein:protein molar ratio $=3.5$, specific antibody protein:protein $=0.12$ ) and the diluted conjugate contained $2 \mathrm{mg} / \mathrm{ml}$ total protein. The slides were then washed in phosphate-buffered saline plus bovine serum albumin and viewed with a Leitz HBO 200 fluorescent microscope equipped with a BG 12 filter (E. Leitz, Inc., Rockleigh, N. J.).

Preparation of epidermal extracts. Extracts were prepared from pure epidermis obtained by heat separation of whole skin. Skin pieces $\left(1 \mathrm{~cm}^{2}\right)$ were placed directly into $0.9 \% \mathrm{NaCl}$ at $55^{\circ} \mathrm{C}$ for $3 \mathrm{~min}$ and then immersed in $0.9 \% \mathrm{NaCl}$ at $0^{\circ} \mathrm{C}$. The epidermis was peeled from the dermis with forceps and placed in a glass tube which contained distilled water. The tissue was sonicated on ice for 630 -s intervals at $100 \mathrm{~W}$ (model W 185, Ultrasonic Instuments International Ltd., Farmingdale, N. Y.), The suspension was centrifuged at $28,000 \times \mathrm{g}$ for $10 \mathrm{~min}$ and the supernate frozen until ready for use.

Preparation of ${ }^{3} \mathrm{H}$-labeled substrate for hydrolytic enzyme assays. Insoluble, ${ }^{3} \mathrm{H}$-labeled epidermal cell material was used as a substrate for the enzyme assays. Whole human skin pieces $\left(4 \mathrm{~mm}^{2} \times 0.3-\mathrm{mm}\right.$ thick) were immersed in $5 \mathrm{ml}$ of $\mathrm{F}-10$ medium (without antibodies) which contained $3 \mu \mathrm{Ci} / \mathrm{ml}{ }^{3} \mathrm{H}$ amino acid mixture and incubated $48 \mathrm{~h}$ in the $\mathrm{CO}_{2}$ incubator. The labeled epidermis was removed from the dermis by the heat/cold treatment, sonicated, passed over lens paper to remove the larger pieces, and the insoluble material from the filtrate collected by centrifugation at $15,000 \mathrm{~g}$ for $10 \mathrm{~min}$. To reduce the background solubilization of this material, the pellet was suspended in $10 \mathrm{ml}$ of $2 \%$ phosphotungstic acid in $0.1 \mathrm{~N} \mathrm{HCl}$, sonicated to provide a finer suspension, and again centrifuged at $15,000 \mathrm{~g}$ for $10 \mathrm{~min}$. The labeled pellet was 

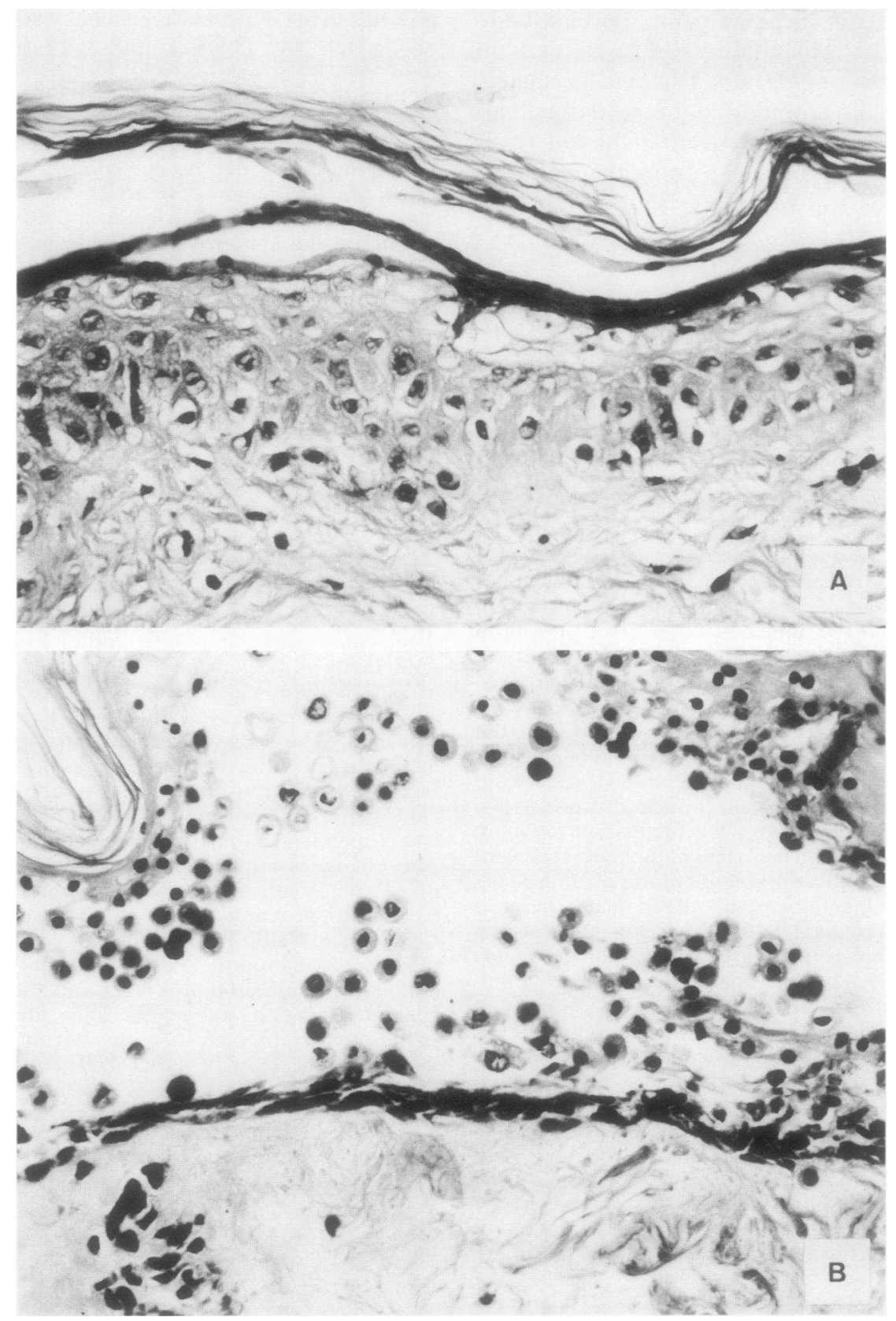

FIGURE 1 Photomicrograph of normal human skin explants which had been cultured $72 \mathrm{~h}$ in F-10 medium which contained $32 \mathrm{mg} / \mathrm{ml}$ normal IgG (A) or $32 \mathrm{mg} / \mathrm{ml}$ pemphigus IgG (B), the latter at an anti-ICS titer of $\mathbf{2 0 0}$ as determined against monkey esophagus substrate. Sections stained with hematoxylin and eosin stain $(\times 180)$.

washed three times, resuspended, and dialyzed against distilled water. This labeled substrate was adjusted to contain approximately $10,000 \mathrm{dpm}$ and $75-100 \mu \mathrm{g}$ protein $/ 0.05 \mathrm{ml}$, and stored frozen until ready for use.

Enzyme assays. The following assay system was used to determine the capacity of fraction I, fraction II, epidermal extracts, or culture medium to solubilize tritium-labeled epidermal material. Assays were carried out in $0.4 \mathrm{ml}$ polypropylene centrifuge tubes (Arthur H. Thomas Co., Phila- delphia, Pa.). The incubation mixture consisted of $0.05 \mathrm{ml}$ of the enzyme source $+0.05 \mathrm{ml}$ of $0.45 \mathrm{M}$ potassium phosphate buffer (at the specified $\mathrm{pH}$ ) $+0.05 \mathrm{ml}$ of the ${ }^{3} \mathrm{H}$ labeled substrate. Replicate tubes were then capped and incubated $20 \mathrm{~h}$ at $37^{\circ} \mathrm{C}$ in a water bath. Appropriate controls included normal or pemphigus IgG in F-10 medium which had incubated in the absence of epidermis, or distilled water in the case of the epidermal extract. After incubation the tubes were centrifuged in a Beckman 152 Microfuge (Beck- 
man Instruments, Inc., Spinco Div., Palo Alto, Calif.) for $4 \mathrm{~min}$, and $0.1 \mathrm{ml}$ of the supernate was removed and counted in the liquid scintillation counter. The remaining pellet was suspended in distilled water, counted, and the percentage of the total radioactivity recovered in the supernate was calculated. Solubilization activity was expressed as change of percent soluble $=$ percent solubilized by the test solution - percent solubilized by the control solution. Background solubilization by the control solutions varied according to the $\mathrm{pH}$ of the assay, but usually did not exceed $5 \%$ of the total labeled substrate.

Sodium dodecyl sulfate polyacrylamide gel electrophoresis. For the double-label experiment shown in Fig. 5, an epidermal cell suspension which contained approximately $10^{7}$ cells was divided in one-half. One-half was incubated $16 \mathrm{~h}$ in $1 \mathrm{ml} \mathrm{F}$-10 medium which contained $37 \mathrm{mg}$ normal IgG $+20 \mu \mathrm{Ci}\left[{ }^{3} \mathrm{H}\right]$ glycine and one-half in $1 \mathrm{ml} \mathrm{F}-10$ medium which contained $37 \mathrm{mg}$ pemphigus IgG $($ anti-ICS titer $=160)$ $+20 \mu \mathrm{Ci}\left[{ }^{14} \mathrm{C}\right]$ glycine. The labeled cultures were sonicated, dialyzed extensively against distilled water, and mixed so that there were approximately equal counts per minute from ${ }^{3} \mathrm{H}$ and ${ }^{14} \mathrm{C}$. The mixtures were adjusted with a stock buffer solution to achieve a final concentration of $0.01 \mathrm{M}$ sodium phosphate buffer, pH 7.0 plus $1.0 \%$ sodium dodecyl sulfate with or without $3 \% 2$-mercaptoethanol. The samples were then boiled $3 \mathrm{~min}$ in a water bath and electrophoresis was performed on $6 \mathrm{~mm} \times 70 \mathrm{~mm} 5 \%$ polyacrylamide disc gels at $8 \mathrm{~mA} /$ tube. The gels were cut into $2-\mathrm{mm}$ slices and solubilized by heating $6 \mathrm{~h}$ in capped scintillation minivials (Fisher Scientific Co.) which contained $0.2 \mathrm{ml} 15 \% \mathrm{H}_{2} \mathrm{O}_{2}$. The radioactivity from ${ }^{3} \mathrm{H}$ and ${ }^{14} \mathrm{C}$ in each slice was determined by a standard double-label counting technique. Molecular weight standardization of the gels was performed with partially reduced human IgG.

\section{RESULTS}

Effects of normal and pemphigus IgG on whole human skin in culture. The effects of normal or pem- phigus IgG on cultured normal human skin is shown in Fig. 1. After $72 \mathrm{~h}$ in culture, the control explant (Fig. 1A) displayed typical artifacts of organ culture, including edema, cellular disorientation, epiboly (growth of the epidermis around the dermis), and the presence of an extensive parakeratotic layer. In contrast, explants which contained pemphigus IgG showed features typical of pemphigus vulgaris lesions. These included a suprabasilar split and the presence of large numbers of acantholytic cells, which are isolated, spherical cells with pyknotic nuclei surrounded by a clear "halo", and an intensely eosinophilic cytoplasm. These cells are characteristic of pemphigus.

Pemphigus IgG binding to epidermal cell suspensions. An epidermal cell suspension was tested by immunofluorescence to determine if the individual cells retained antigen(s) capable of reacting with the pemphigus antibody. As seen in Fig. 2, 60-70\% of the cells showed intense fluorescence which was concentrated on the surface. We assume that the antigens were lost in the remaining cells, possibly as a result of trypsinization, or that they were not present in the intact epidermis. In suspensions which had incubated with normal IgG, only an occasional fluorescent cell was seen

Effects of normal and pemphigus IgG on epidermal cell suspensions. Table I contains the results of five separate experiments in which epidermal cell suspensions were incubated with a ${ }^{3} \mathrm{H}$-amino acid mixture for 18-h periods in the presence of pemphigus IgG or normal human serum IgG. The variations in total incorporation of radioactivity among the five experi-

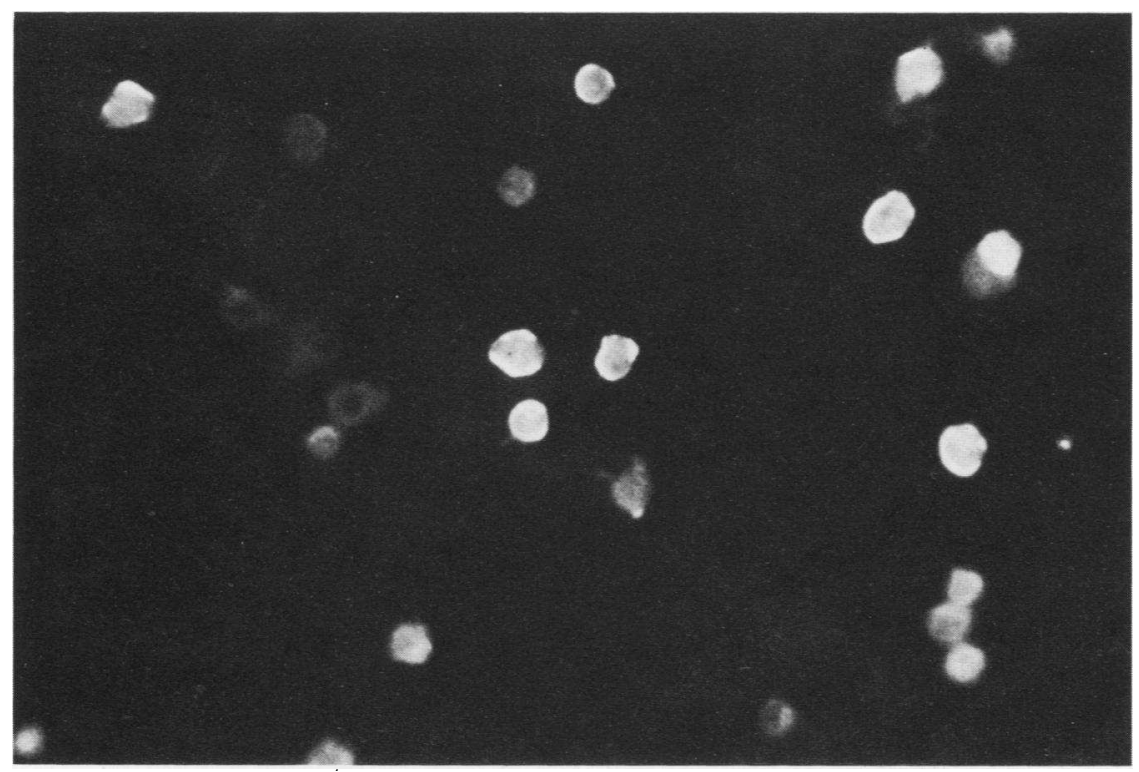

FIGURE 2 Fluorescence photomicrograph of an epidermal cell suspension which had incubated $1 \mathrm{~h}$ with F-10 medium which contained pemphigus IgG and then stained with a fluoresceinconjugated, goat antihuman IgG $(\times 250)$. 
TABLE I

Effects of Normal and Pemphigus IgG on the Accumulation and Partitioning of Newly Synthesized Proteins by Human Epidermal Cells in Suspension Culture

\begin{tabular}{|c|c|c|c|c|c|c|c|c|c|}
\hline \multirow[b]{2}{*}{ Experiment } & \multicolumn{2}{|c|}{ Total dpm per culture } & \multirow{2}{*}{$\begin{array}{c}\text { Percent } \\
\text { inhibition }\end{array}$} & \multicolumn{2}{|c|}{$\begin{array}{l}\text { Percent of total dpm } \\
\text { in fraction I }\end{array}$} & \multicolumn{2}{|c|}{$\begin{array}{l}\text { Percent of total dpm } \\
\text { in fraction II }\end{array}$} & \multicolumn{2}{|c|}{$\begin{array}{l}\text { Percent of total dpm } \\
\text { in fraction III }\end{array}$} \\
\hline & NIgG & PIgG & & NIgG* & PIgG $\$$ & NIgG & PIgG & NIgG & PIgG \\
\hline 1 & 710,742 & 364,314 & 48.7 & 47.6 & 81.8 & 12.0 & 4.8 & 40.4 & 13.5 \\
\hline 2 & 178,566 & 53,157 & 70.2 & 28.4 & 79.9 & 20.4 & 5.3 & 51.3 & 14.8 \\
\hline 3 & 57,343 & 31,893 & 44.4 & 51.3 & 66.1 & 8.8 & 20.5 & 39.8 & 13.4 \\
\hline 4 & $2,725,688$ & 912,656 & 66.5 & - & - & - & - & - & - \\
\hline 5 & 76,704 & 34,091 & 55.6 & - & - & - & - & - & - \\
\hline $\begin{array}{l}\text { Mean } \\
\pm S D\end{array}$ & - & 一 & $\begin{array}{r}57.1 \\
\pm 11.1\end{array}$ & $\begin{array}{r}42.4 \\
\pm 12.3\end{array}$ & $\begin{array}{r}75.9 \\
\pm 8.6\end{array}$ & $\begin{array}{r}13.7 \\
\pm 6.0\end{array}$ & $\begin{array}{r}10.2 \\
\pm 8.9\end{array}$ & $\begin{array}{r}43.8 \\
\pm 6.5\end{array}$ & $\begin{array}{r}13.9 \\
\pm 0.8\end{array}$ \\
\hline
\end{tabular}

Epidermal cells from five different patients were incubated for 18-h periods in F-10 medium which contained either pemphigus IgG or an identical concentration of normal IgG from AB blood-type donors $+\left[{ }^{3} \mathrm{H}\right]$ amino acid mixture. In all the experiments, total nondialyzable radioactivity was determined and in experiments $1-3$, fractions I, II, and III were collected.

* NIgG = normal IgG.

$\ddagger$ PIgG = pemphigus IgG.

ments in Table I are a result of inherent differences in skin samples, cell numbers, amounts of radioactivity, and antibody concentrations used. However, these factors were always controlled within a given experiment. Consequently, the differences in each experiment between the effect of normal IgG and pemphigus IgG were a result of the effects of the antibodies. Relative to the controls, pemphigus IgG caused a dramatic reduction $(57 \pm 11 \%)$ in the total accumulation of newly synthesized proteins during the 18 -h incubation periods. Furthermore, the viability of the cells, as assessed by trypan blue exclusion at the start and at the finish of the incubations, showed only $14 \%$ of the viable cells incubated with normal IgG were killed as compared to $75 \%$ of those incubated with pemphigus IgG.

There were also striking differences in partitioning of newly synthesized proteins into fractions I, II, and III (Table I, experiments 1-3). The percentage of total radioactivity recovered in each of the three fractions varied depending upon which antibody was present during the pulse. Pemphigus IgG caused a shift in labeled protein from the insoluble fraction III ( $44 \%$ in the control IgG, $14 \%$ in the pemphigus IgG) to the soluble extracellular fraction I (42\% in the control IgG, $76 \%$ in the pemphigus IgG). Thus, the experiments shown in Table I suggest that during 18-h incubation periods, pemphigus IgG had two major effects on epidermal cells: $(a)$ a reduction in the accumulation of newly synthesized proteins, and $(b)$ a change in the distribution of the newly synthesized proteins from an insoluble cellular fraction to an extracellular soluble fraction.

Concentration effects of normal and pemphigus IgG on epidermal cell suspensions. The concentration effects of normal and pemphigus IgG on accumulation and partitioning of proteins was determined. Total accumulation of protein (Fig. 3, upper panel) increased with increasing antibody concentrations up to about $4.5 \mathrm{mg} / \mathrm{ml}$ (ICS titer $=50$ ), although at the lower concentrations the pemphigus IgG caused a significant increase over the controls. We have no explanation for this "low-dose" effect of the pemphigus IgG, but the phenomenon appears to be reproducible. At higher antibody concentrations, total protein accumulation in the controls remained constant, whereas pemphigus IgG caused a reduction. Maximal reduction occurred at a pemphigus antibody titer of 150 , and the extent of the reduction ( $\cong 65 \%$ in this experiment) was similar to the experiments listed in Table I.

In this same experiment, pemphigus IgG caused a concentration-dependent shift in partitioning of the newly synthesized proteins to the soluble extracellular fraction I. The increased percentage of protein recovered in fraction I after incubation with pemphigus IgG (center panel) was accompanied by decreased cell-associated fractions II and III (lower panel). This shift in partitioning from insoluble to soluble fractions occurred at pemphigus antibody concentrations which caused reductions in total protein accumulation.

Kinetics of normal and pemphigus IgG effects on epidermal cell suspensions. The time course for the pemphigus IgG effects on accumulation and partitioning of proteins was determined. This is shown in Fig. 4. The sum of the radioactivity present in fractions I, II, and III after incubation with normal IgG or with pemphigus IgG are plotted in the upper panel. In the controls, proteins continued to accumulate throughout the $4 \mathrm{~h}$ of the experiment, although at declining rates. 

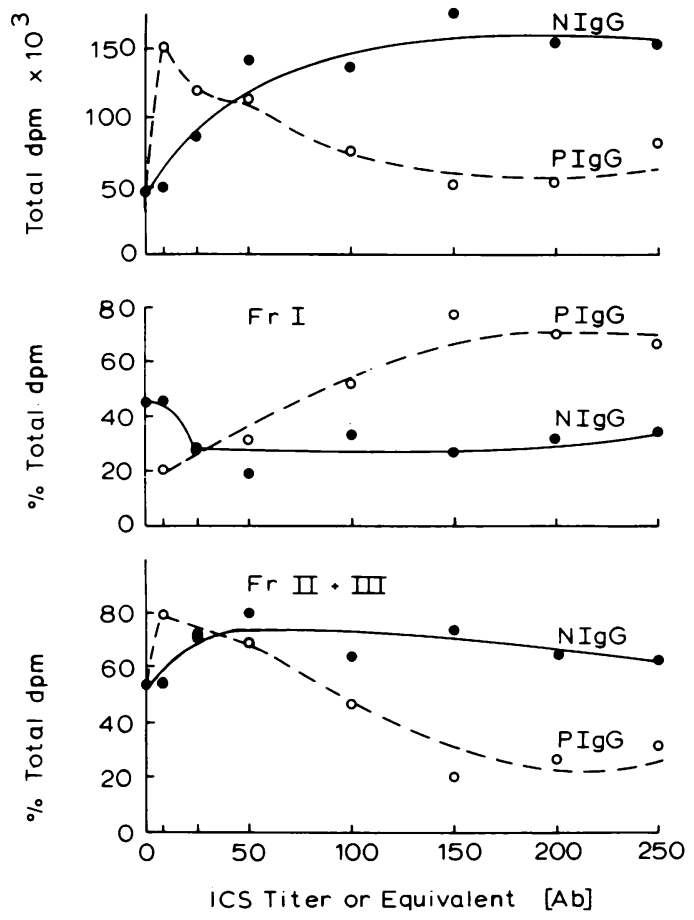

FIGURE 3 Concentration effects of normal or pemphigus IgG on the accumulation and partitioning of proteins by human epidermal cell suspensions. $2.7 \times 10^{5}$ viable cells were pipetted into separate sterile Falcon culture tubes. The incubation medium $(0.6 \mathrm{ml}$ final vol $)$ consisted of $\mathrm{F}-10$ medium with only 0.01 times the normal amino acid concentrations $+5 \mu \mathrm{Ci}\left[{ }^{3} \mathrm{H}\right]$ amino acid mixture (NET-250, New England Nuclear) + pemphigus IgG or normal IgG at the indicated concentrations. At the pemphigus IgG anti-ICS titer of 250 , the protein concentration was $19 \mathrm{mg} / \mathrm{ml}$ and the normal IgG was adjusted to the same protein concentrations. The cultures were incubated $18 \mathrm{~h}$ at $37^{\circ} \mathrm{C}$ in a humid atmosphere which contained $5 \% \quad \mathrm{CO}_{2}: 95 \%$ air. At the end of the incubation period, fractions (Fr) I, II, and III, were prepared. Upper panel, total accumulation into fractions I + II + III; center panel, percent of the total radioactivity recovered in fraction I; lower panel, percent of the total radioactivity recovered in fractions II + III. NIgG: normal IgG; PIgG: pemphigus IgG.

In the presence of the pemphigus antibody, the rates of accumulation paralleled the controls during the first $1.5 \mathrm{~h}$, at which time further accumulation ceased.

The effect of control IgG on the accumulation of fractions I, II, and III is shown in the center panel of Fig. 4. The labeling of the extracellular fraction I occurred rapidly and after $30 \mathrm{~min}$ accounted for about $80 \%$ of the total radioactive material. After $60 \mathrm{~min}$ this material began to reach equilibrium and after a lag period, fraction III began to accumulate. The intracellular fraction II accumulated at a constant rate and accounted for only $10-15 \%$ of the total radioactivity throughout the experiment. The effects of pemphigus IgG on the accumulation of the three fractions are shown in the lower panel of Fig. 4. During the first $2 \mathrm{~h}$ there was little difference between control and pemphigus IgG-treated cultures. At $2 \mathrm{~h}$, fraction III accounted for approximately $30 \%$ of the total radioactivity in the normal IgG controls and $38 \%$ in the pemphigus IgG cultures. At this time, however, a rapid loss of radioactivity from the insoluble fraction III began to occur in pemphigus IgG-treated cultures and by $3 \mathrm{~h}$ fraction III accounted for only about $11 \%$ of the total radioactivity. By contrast, fraction III comprised $41 \%$ of the control cultures at $3 \mathrm{~h}$. Thus, in $1 \mathrm{~h}$ in the presence of pemphigus IgG more than $70 \%$ of the preformed insoluble material (fraction III) become solubilized. The isotopically-labeled material lost from fraction III was probably recovered in fraction I. Repeat experiments have demonstrated similar timedependent shifts in partitioning.

Molecular weight distribution of proteins which accumulate in the presence of control and pemphigus

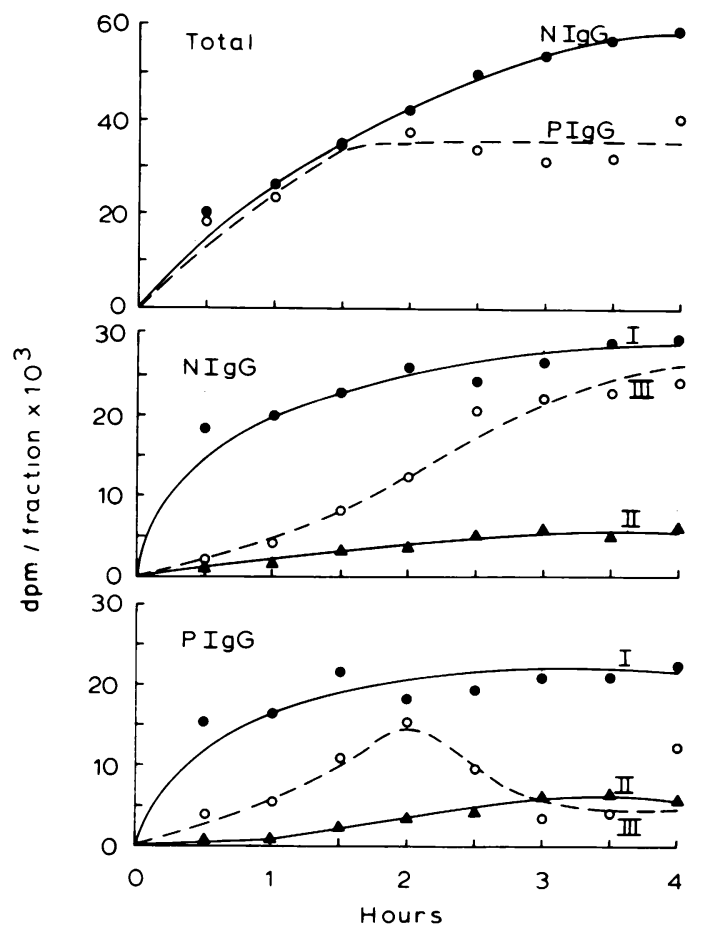

FIGURE 4 Time-dependent effects of normal or pemphigus IgG on the accumulation and partitioning of proteins by human epidermal cell suspensions. Epidermal cells were incubated as described in the legend to Fig. 3. Specific culture conditions were as follows: total vol $0.6 \mathrm{ml}$ per culture, 2.1 $\times 10^{5}$ viable cells per culture, pemphigus IgG anti-ICS titer $=150$, normal and pemphigus IgG protein concentration $11.4 \mathrm{mg} / \mathrm{ml}, 5 \mu \mathrm{Ci}$ per culture ${ }^{3} \mathrm{H}$-amino acid mixture. At the indicated times, cultures were removed and fractions $I$, II, and III were prepared. Upper panel, total accumulation into fractions I + II + III in the normal IgG cultures (NIgG) and in the pemphigus IgG cultures (PIgG). Center panel, accumulation into fraction I (I), fraction II (II), and fraction III (III) of the normal IgG controls. Lower panel, accumulation into fraction I (I), fraction II (II), and fraction III (III) of the pemphigus IgG cultures. 
IgG. The preceding experiments showed that the major effects of pemphigus IgG on human epidermal cells were to prevent the accumulation of newly synthesized proteins and to lead to solubilization of insoluble proteins. As an initial approach to defining the mechanism(s) of these two phenomena, a double-label technique was employed which allowed for direct comparison of the molecular weight profiles of the proteins accumulated by epidermal cells cultured with normal or pemphigus IgG. The results are shown in Fig. 5. In the upper panel it is seen that in cells treated with control IgG (closed circles) six or seven major molecular weight groups of proteins were present. These ranged in size from about 124,000 to 12,000 mol wt units. In samples reduced with mercaptoethanol (lower panel, closed circles) the larger 124,000-mol wt species disappeared and, as shown by crude measurement of peak areas or peak heights, was probably converted to smaller species of 43,000 and $27,000 \mathrm{~mol} \mathrm{wt}$ units. The profile of proteins which accumulated in the presence of pemphigus IgG was quite different. A much larger percentage of the total radioactivity was found in the large molecular weight peak (upper panel, open circles), and no peaks were seen at 70,000, 43,000, and $12,000 \mathrm{~mol}$ wt units. Mercaptoethanol treatment re-

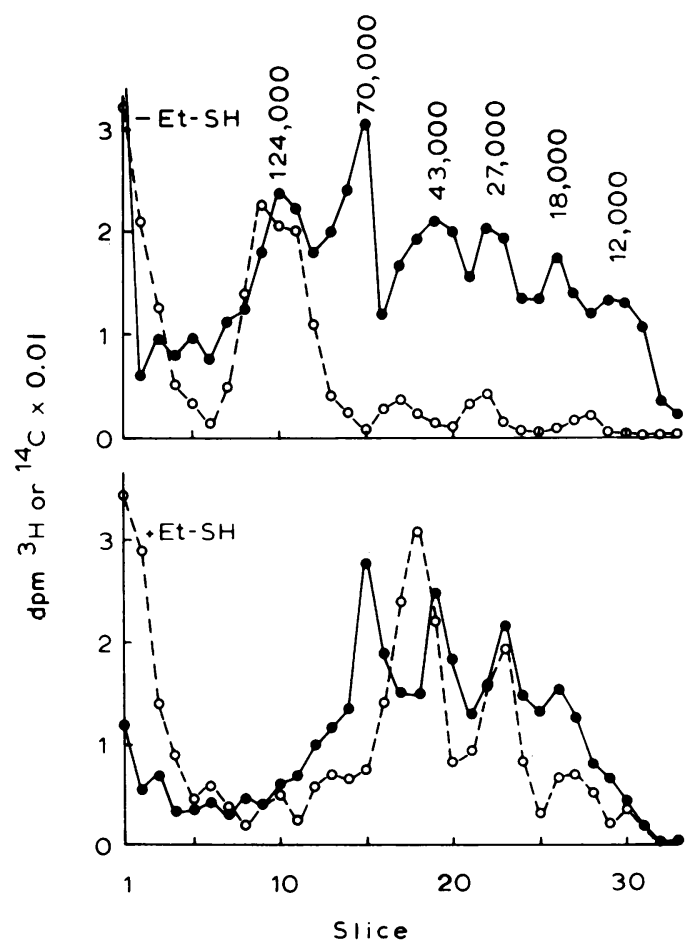

FIGURE 5 Sodium dodecyl sulfate polyacrylamide gel electrophoresis profiles of the newly synthesized proteins from epidermal cell suspensions which had incubated $16 \mathrm{~h}$ with normal IgG $(-O)$ or pemphigus IgG $\left(\mathrm{O}_{--} \mathrm{O}^{-}\right.$). Details are presented in Methods. Upper panel, no mercaptoethanol; lower panel, 3\% mercaptoethanol. Et-SH: Ethylmercaptan. duced the larger 124,000 mol wt peak to components with mol wt of 51,000 and 27,000. These data indicate that qualitative differences exist in the proteins which accumulate in human epidermal cell cultures incubated with normal or pemphigus IgG.

Evidence that epidermal enzymes are responsible for solubilization of labeled fraction III. One explanation for the solubilization of fraction III is that pemphigus IgG induced the release of hydrolytic enzymes from the keratinocytes. If this occurred, then it would be expected that in cultures grown in the presence of pemphigus IgG, enzymatic activity would be recovered in the extracellular fraction I. In contrast, in cultures incubated with normal IgG, such activity would remain in the intracellular fraction II. In initial experiments, fractions I and II from epidermal cell cultures were assayed for typical lysosomal hydrolases, including $\beta$-glucuronidase, aryl sulfatase, and acid phosphatase, and for the neutral cytoplasmic protease leucine aminopeptidase. No hydrolytic activity was detected in these fractions or in extracts from equivalent numbers of whole epidermal cells, probably as a result of lack of sensitivity of the colorimetric methods used. As another approach to detect hydrolytic activity, an assay system was devised which utilized ${ }^{3} \mathrm{H}$-labeled insoluble epidermal cell material as an enzyme substrate (Methods). In a series of experiments it was

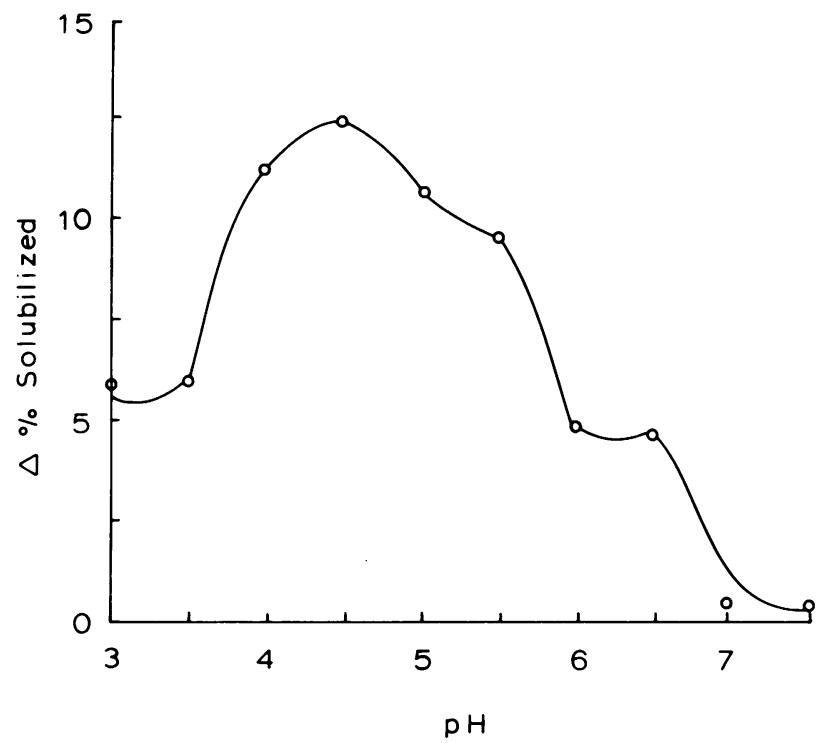

FIGURE 6 Activity vs. pH profiles of extracts from human epidermis. Epidermal extracts were prepared from normal human skin and assayed for the capacity to solubilize radioactively-labeled insoluble epidermal cell material (Methods). Each point represents an average value of duplicate assays from three separate experiments. Each experiment used skin from a different patient, each $\cong$ a $20-\mathrm{cm}^{2}$ area. Each assay tube contained $\cong 12,000 \mathrm{dpm}{ }^{3} \mathrm{H}$-substrate $(80 \mu \mathrm{g}$ protein). The average background solubilization by the distilled water controls was $4.9 \pm 1.1 \%$ of this radioactivity. 
shown that extracts from normal human epidermis had the capacity to solubilize this labeled substrate. The solubilizing activity was $\mathrm{pH}$-sensitive with broad $\mathrm{pH}$ optima between 3 and 6.5 (Fig. 6). This suggested that more than one enzyme was involved. The enzymatic nature of the solubilization was further shown, because boiling the extracts for $15 \mathrm{~min}$ destroyed the activity and $60-70 \%$ of the solubilized radioactivity was dialyzable.

To determine if pemphigus IgG caused release of enzymes from the cell, we assayed for hydrolytic activity in fractions I and II from cell suspensions which had incubated $18 \mathrm{~h}$ with normal or pemphigus IgG. These fractions did possess activity, but the total which could be demonstrated from cell suspensions was quite small, and amounted to $<10 \%$ of that seen in epidermal extracts. In an attempt to increase activity, we modified the previous experiment and cultured intact whole epidermis for $48 \mathrm{~h}$ in normal or pemphigus IgG and again assayed fractions I and II. The assays were conducted between pH 3 and 7.5 to distinguish between acid and neutral hydrolases. When the activity vs. $\mathrm{pH}$ profiles of these fractions were compared (Fig. 7), it is clear that in cultures which contain epidermis and pemphigus IgG, most of the hydrolase activity was

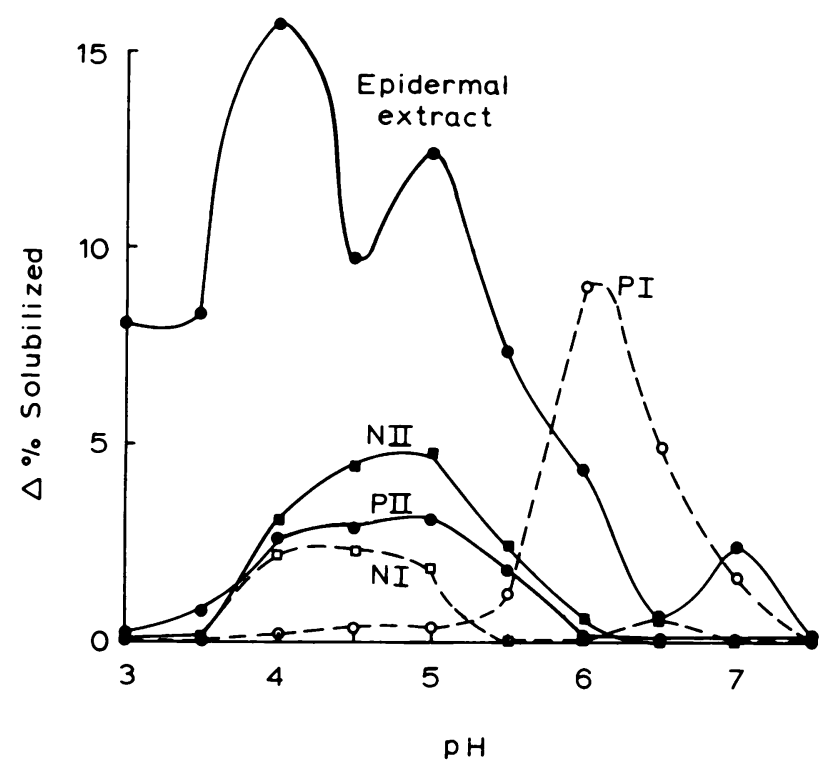

FIGURE 7 Activity vs. pH profiles of the medium (fraction I) or soluble intracellular fraction (fraction II) from whole epidermis which had incubated $48 \mathrm{~h}$ with normal IgG or pemphigus IgG $(24 \mathrm{mg} / \mathrm{ml}$ protein, anti-ICS titer $=160)$. The activity profile of an epidermal extract from the same patient is included. NI and PI represent the activities of fractions I from epidermal cultures incubated with normal IgG or pemphigus IgG, respectively. NII and PII represent the activities of fractions II from cultures incubated with normal IgG or pemphigus IgG. The assay conditions were as described in the legend to Fig. 6.

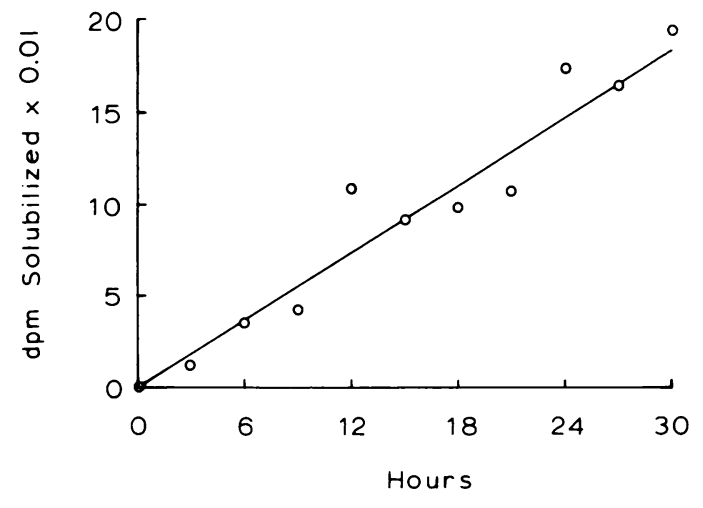

Figure 8 Time-dependent solubilization of radioactive substrate by PI. Fraction I from cultures which had incubated $48 \mathrm{~h}$ with pemphigus IgG (PI) was incubated with labeled substrate at $\mathrm{pH}$ 6.5. At the indicated times, samples were centrifuged and the soluble radioactivity determined. Each point represents the average soluble radioactivity from three tubes, each containing $14,500 \mathrm{dpm}$ substrate.

recovered in fraction $\mathrm{I}(\mathrm{PI})$ at $\mathrm{pH} 6$ and 6.5. Fraction $\mathrm{I}$ from the control (NI) was devoid of this activity. In both cultures, the intracellular fraction II (NII and PII) enzymes had more acidic pH optima. For purposes of comparison, the $\mathrm{pH}$ profile of an epidermal extract from the same patient was determined at the same time, and is included in Fig. 7.

The solubilization of ${ }^{3} \mathrm{H}$-labeled epidermal substrate by fraction I from pemphigus IgG-treated epidermal cultures was linear during a 30 -h incubation period (Fig. 8). During this time, $\cong 13 \%$ of the total substrate radioactivity became soluble. Background solubilization by pemphigus IgG or by fraction I from cultures treated with normal IgG were equal and amounted to only $3 \%$ of the total radioactivity. Solubilization activity was also linear with respect to fraction I concentration (not shown).

\section{DISCUSSION}

The results presented here have demonstrated that the pemphigus antibody binds to the surface of human epidermal cells which have been prepared by trypsinization. This supports the observations of Brigden and Amos (19) that guinea pig epidermal cells prepared by trypsinization can bind pemphigus or pemphigoid antibodies. It is thought that the pemphigus antibody binds to antigens which are located in the ICS of the epidermis. It is clear, however, that the antigens are actually located in the cell surface, and that the ICS is probably only an extension of the cell surface. This concept that the antibody binds to the cell instead of to an inert, extracellular "cement" substance is important in understanding the mechanism of pemphigus acantholysis. When the antibody is bound, certain characteristic responses are evoked 
from the cell. Our results show that the cellular response consists of $(a)$ reduced accumulation of newly synthesized proteins and $(b)$ a shift in partitioning of the newly synthesized proteins from an insoluble phase to a soluble phase. These effects are dependent upon antibody concentration and, at titers below 50 , the effects were not seen. There appeared to be a stimulation of protein synthesis at low pemphigus antibody titers, although we cannot explain the significance of this observation. Our data suggested that inhibition of accumulation preceded solubilization by about $1 \mathrm{~h}$, at which time rapid solubilization of about $70 \%$ of the preformed insoluble material occurred. This solubilization appeared to be mediated by hydrolytic enzymes which were released or activated by the keratinocyte. After incubation of whole epidermis for 2 days with pemphigus IgG, hydrolase activity with $\mathrm{pH}$ optima between 6 and 6.5 was recovered in the medium. This activity was not released by epidermis which had been cultured with normal IgG, and acid hydrolases remained in the cells in both cultures. This differential appearance of $\mathrm{pH}$ 6- to 6.5-active hydrolases in pemphigus IgG-treated cultures suggests the possibility that these enzyme(s), induced or activated as a result of keratinocyte interaction with pemphigus IgG, are involved in the acantholysis of pemphigus.

The concept that enzymes are involved in pemphigus acantholysis is not new, and several studies have advanced such a mechanism. Various proteolytic enzymes, which include trypsin (20), chymotrypsin (21), and papain or elastase (22), are capable of producing epidermal acantholysis when injected into excised skin, and Stoughton (23) extracted an enzyme(s) from the feces of patients with ulcerative colitis which caused acantholysis on formalin-fixed skin sections. Evidence that the source of hydrolytic enzymes is the skin itself includes the observation that mild heating of excised skin specimens produced acantholysis and dermal-epidermal separation, both of which were prevented by sulfhydryl inhibitors (24). Acantholysis induced by cantharidin also appears to be mediated by enzymes (24). Our model differs in that the stimulus for acantholysis is provided by the pemphigus autoantibody.

In a recent study, Farb et al. (25) have shown that cultured monolayers of mouse epidermal cells grown in $2 \%$ pemphigus serum became detached from the culture dish more easily than cells grown in normal serum. This effect was prevented by soybean trypsin inhibitor and $\alpha_{2}$-macroglobulin. They postulated that this phenomenon, as well as acantholysis, was mediated by the release or activation of a neutral protease from the epidermal cells. They also reported that $2 \%$ pemphigus serum had no effect on protein synthesis by these cells. This is not surprising, because the resulting titer of the pemphigus antibody in their experi- mental system was $<10$. Our experiments clearly demonstrated that protein synthesis was unaffected by antibody titers lower than $\mathbf{5 0}$. It is possible that these low titers induced the release of small quantities of enzymes between the cell surface and the culture dish and caused the observed poor adherence of cells, but that the amounts were insufficient to cause cellular damage and inhibition of protein synthesis.

We have examined two other cultured cell lines for interaction with pemphigus IgG (unpublished results). Even at high antibody titers, we could not demonstrate antibody binding to guinea pig epidermal cells in monolayer culture and could not demonstrate effects on protein synthesis, partitioning, or cell viability. On the other hand, the BE cell line (derived from human epidermis (26)) did display weak binding of pemphigus IgG. This interaction resulted in a small shift in the partitioning of proteins from the insoluble phase, but there was no effect on total protein synthesis or cell viability. That guinea pig epidermal monolayer cultures did not react with pemphigus IgG is not surprising, and perhaps predictable. The cells in these cultures are replicating and, by definition, the only epidermal cell type which is capable of replication in vivo or in vitro is the basal cell. The basal cell is not a target cell for the pemphigus antibody. On the other hand, the BE cell is a transformed cell line and therefore not a "normal" basal cell. This may explain the binding of pemphigus antibodies to this cell and the small shift in partitioning we observed.

The pemphigus IgG-associated decrease in radioactively labeled proteins by cell suspensions could result from inhibition of protein synthesis and(or) by increased degradation as a result of hydrolytic enzyme activity. The experiments presented here do not allow for an evaluation as to the extent to which these opposing processes contributed to the overall accumulation. We do feel confident, however, that degradation and inhibition of protein synthesis both occurred, even though we cannot be certain which occurred first. The experiments which deal with hydrolytic enzyme activities support the conclusion that degradation played a role. Evidence that protein synthesis was inhibited is less direct. Kinetic studies demonstrated that accumulation of newly synthesized proteins ceased nearly $1 \mathrm{~h}$ before solubilization began, and suggested that hydrolytic enzymes were released or activated after the inhibitory effect on protein synthesis. In autoradiographic experiments with whole skin in organ culture $(6,7)$ we showed that during 2 -h pulses with $\left[{ }^{3} \mathrm{H}\right]$ uridine or ${ }^{3} \mathrm{H}$-amino acids, the suprabasilar autoantibody "target" cells were completely devoid of silver grains at a time when the basal cells were unaffected. Because both cell types shared a common milieu, it is unlikely that hydrolytic enzymes would have differentially degraded only the macro- 
molecules of the target cells. Finally, because $75 \%$ of the cells cultured with pemphigus IgG did not exclude trypan blue, it must be assumed that they were no longer viable, and would not synthesize protein. Despite evidence that protein synthesis was inhibited in epidermal cells after interaction with pemphigus IgG, it is clear that more was involved in the process than simple inhibition. When the molecular weight profiles of the labeled proteins which accumulated in control or pemphigus IgG-treated cultures were compared by a double-label technique with sodium dodecyl sulfate polyacrylamide gel electrophoresis, qualitative differences were noted. These differences could have resulted from differential inhibition of some species and(or) partial degradation of similar species.

It is important to emphasize that the effects of pemphigus IgG seen in cell suspension culture, whole epidermal culture, or whole skin culture were independent of complement, and consequently the classical mechanisms by which antibodies lyse cells do not apply to pemphigus IgG. This is consistent with the known fact that the pemphigus antibody does not fix complement in vitro $(27,28)$. Although reaction products from complement activation have been found in the blister fluid from pemphigus patients (29) and C3, $\mathrm{Clq}, \mathrm{C} 3 \mathrm{PA}$, and properdin have been found to be deposited in the acantholytic lesion (30), these products are not deposited with the autoantibody in perilesional skin, and may only represent secondary reactions as a response to the lesion. The exact role of complement in producing tissue damage in pemphigus remains to be established.

We propose the following events to account for the mechanism of pemphigus acantholysis. Initially, the antibody interacts with antigen(s) located on the surface of the epidermal suprabasilar target cell and this interaction results in a perturbation of the cell surface. As a result, the integrity of the surface is lost, and at some point RNA and protein synthesis ceases. One can speculate that formation of immune complexes could in a somewhat nonspecific way interfere with normal cell function, for example by upsetting delicate balances between the normal feedback mechanisms for synthesis and turnover of key components of the cell surface and ICS. As a result of these perturbations, hydrolytic enzymes are released, induced, or activated from the keratinocyte and autolysis begins to occur. The enzymes which underwrite this autolysis are of such a nature that the characteristic acantholytic cell is produced.

\section{ACKNOWLEDGMENT}

This study was supported by National Institutes of Health grant AM 19115.

\section{REFERENCES}

1. Civatte, A. 1943. Diagnostic histopathologique de la dermatite polymorphe douloureuse ou maladie de Duhring-Brocq. Ann. Dermatol. Syphiligr. 3: 1-30.

2. Beutner, E., W. Lever, E. Witebsky, R. Jordon, and B. Chertock. 1965. Autoantibodies in pemphigus vulgaris: response to an intercellular substance of epidermis. JAMA (J. Am. Med. Assoc.). 192: 682-688.

3. Beutner, E., and R. Jordon. 1964. Demonstration of skin antibodies in sera of pemphigus vulgaris patients by indirect immunofluorescent staining. Proc. Soc. Exp. Biol. Med. 117: 505-510.

4. Bellone, A., and V. Leone. 1956. Ricerche sull'influenza esercitata da sieri di soggetti sani o affetti da pemfigo su pelle umana normale e pemfigosa coltivata "in vitro". G. Ital. Dermatol. Sifilol. 97: 97-109.

5. Michel, B., and C. Ko. 1974. Effect of pemphigus or bullous pemphigoid sera and leukocytes on normal skin in organ culture. An in vitro model for the study of bullous diseases. J. Invest. Dermatol. 62: 541. (Abstr.)

6. Schiltz, J., and B. Michel. 1976. Effects of the pemphigus autoantibody on human epidermal cells in organ or suspension culture. J. Invest. Dermatol. 66: 279. (Abstr.)

7. Schiltz, J., and B. Michel. 1976. Production of epidermal acantholysis in normal human skin in vitro by the IgG fraction from pemphigus serum. J. Invest. Dermatol. 67: 254-260.

8. Michel, B., and C. Ko. 1977. An organ culture model for the study of pemphigus acantholysis. Br. J. Dermatol. 96: $295-302$.

9. Deng, J., E. Beutner, J. Shu, and T. Chorzelski. 1977. Pemphigus antibody action on skin explants. Kinetics of acantholytic changes and stability of antigens in tissue cultures of normal monkey skin explants. Arch. Dermatol. 113: 923-926.

10. Barnett, M., E. Beutner, and T. Chorzelski. 1977. Organ culture studies of pemphigus antibodies. II. Ultrastructural comparison between acantholytic changes in vitro and human pemphigus lesions. J. Invest. Dermatol. 68: 265-271.

11. Hu, C., B. Michel, and J. Schiltz. 1978. Epidermal acantholysis induced in vitro by pemphigus autoantibody: An ultrastructural study. Am. J. Pathol. 90: 345-362.

12. Hashimoto, K., and W. Lever. 1967. An electron microscopic study of pemphigus vulgaris of the mouth and the skin with special reference to the intercellular cement. J. Invest. Dermatol. 48: 540-552.

13. Briggaman, R., and C. Wheeler. 1968. Epidermal-dermal interactions in adult human skin; role of dermis in epidermal maintenance. J. Invest. Dermatol. 51: 454-465.

14. Ham, R. 1965. Clonal growth of mammalian cells in a chemically-defined synthetic medium. Proc. Natl. Acad. Sci. U. S. A. 53: 288-293.

15. Deutsch, H. F. 1968. Preparation of immunoglobulin concentrates. Methods Immunol. Immunochem. 1: 315321.

16. Grob, P., and T. Inderbitzen. 1967. Pemphigus antigen and bloodgroup substances A and B. J. Invest. Dermatol. 49: 285-287.

17. Beutner, E., T. Chorzelski, and R. Jordon. 1970. Autosensitization in Pemphigus and Bullous Pemphigoid. Charles C. Thomas, Publisher. Springfield, Ill. 32.

18. Schiltz, J., J. Rosenbloom, and G. Levenson. 1977. The effects of ascorbic acid deficiency on collagen synthesis by mouse molar tooth germs in organ culture. J. Embryol. Exp. Morphol. 37: 49-57.

19. Brigden, W., and H. Amos. 1975. The differential binding 
of antibody from the sera of patients with pemphigus and pemphigoid to isolated guinea pig epidermal cells. $\mathrm{Br}$. J. Dermatol. 93: 425-430.

20. Hambrick, G., Jr., and H. Blank. 1954. Whole mounts for the study of skin and its appendages. J. Invest. Dermatol. 23: 437-453.

21. Scott, A. 1958. A study of the action of chymotrypsin on the skin. J. Invest. Dermatol. 30: 201-205.

22. Stoughton, R., and F. Bagatell. 1959. The nature of cantharidin acantholysis. J. Invest. Dermatol. 33: 287-292.

23. Stoughton, R. 1952. Enzymatic cytolysis of epithelium by gel filtration of feces of patients with ulcerative colitis. Science (Wash. D. C.). 116: 37-39.

24. Stoughton, R., and N. Novak. 1956. Disruption of tonofibrils and intercellular bridges by disulfide-splitting agents. J. Invest. Dermatol. 26: 127-136.

25. Farb, R., R. Dykes, and G. Lazarus. 1978. Anti-epidermalcell-surface pemphigus antibody detaches viable epi- dermal cells from culture plates by activation of proteinase. Proc. Natl. Acad. Sci. U. S. A. 75: 459-463.

26. Eisinger, M., O. Kucarova, N. Sarkar, and R. Good. 1975. Propagation of human wart virus in tissue culture. Nature (Lond.). 256: 432-434.

27. Jordon, R., W. Sams, Jr., G. Diaz, and E. Beutner. 1971. Negative complement immunofluorescence in pemphigus. J. Invest. Dermatol. 57: 407-410.

28. Sams, W., Jr., and P. Schur. 1973. Studies of the antibodies in pemphigoid and pemphigus. J. Lab. Clin. Med. 82: 249-254.

29. Jordon, R., N. Day, J. Luckasen, and R. Good. 1973. Complement activation in pemphigus vulgaris blister fluid. Clin. Exp. Immunol. 15: 53-63.

30. Jordon, R., A. Schroeter, R. Rogers III, and H. Perry. 1974. Classical and alternate pathway activation of complement in pemphigus vulgaris lesions. J. Invest. Dermatol. 63: 256-259. 